Turbocharging the Internal Combustion Engine 


\section{Turbocharging the Internal Combustion Engine}

N. Watson

Reader in Mechanical Engineering, Imperial College, London

the late M. S. Janota

Professor of Mechanical Engineering, Queen Mary College, London 
(C) N. Watson and M. S. Janota 1982

Softcover reprint of the hardcover 1st edition 1982

All rights reserved. No part of this publication may be reproduced or transmitted, in any form or by any means, without permission.

This book is printed on paper suitable for recycling and made from fully managed and sustained forest sources. Logging, pulping and manufacturing processes are expected to conform to the environmental regulations of the country of origin.

First published 1982 by

THE MACMILLAN PRESS LTD

London and Basingstoke

Companies and representatives

throughout the world

Typeset in 10/11 Times by

MULTIPLEX techniques ltd., Orpington, Kent

ISBN 978-1-349-04026-1

ISBN 978-1-349-04024-7 (eBook)

DOI 10.1007/978-1-349-04024-7 


\section{Contents}

Preface $\quad$ x

Nomenclature xiii

1. Introduction to Turbocharging and Turbochargers 1

$\begin{array}{lll}1.1 & \text { Supercharging } & 1\end{array}$

$\begin{array}{lll}1.2 & \text { Turbocharging } & 4\end{array}$

1.3 Turbocharging the Two-stroke Engine 11

$\begin{array}{lll}1.4 & \text { Charge Cooling } & 12\end{array}$

$\begin{array}{ll}1.5 & 13\end{array}$

$\begin{array}{ll}1.6 \text { Gas-generator Power Plant } & 14\end{array}$

1.7 Turbocharging the Spark-ignition Engine 15

$\begin{array}{lll}1.8 & \text { Engine Efficiency } & 17\end{array}$

2. Turbochargers 19

$\begin{array}{ll}2.1 \text { Introduction } & 19\end{array}$

$\begin{array}{ll}2.2 \text { Turbomachines } & 19\end{array}$

2.3 Total and Static Pressure and Temperature 23

$\begin{array}{lll}2.4 & \text { Compressor and Turbine Efficiencies } & 23\end{array}$

2.5 Non-dimensional Representation of Compressor and Turbine Performance Characteristics 31

2.6 Performance Characteristics of Compressors, Turbines and
Turbochargers

$\begin{array}{lll}2.7 & \text { Turbochargers } & 37\end{array}$

3. The Radial Flow Compressor 73

$\begin{array}{lll}3.1 & \text { Introduction } & 73\end{array}$

$\begin{array}{lll}3.2 & \text { Elementary Theory } & 74\end{array}$

3.3 One-dimensional Flow Analysis through the Radial Flow

3.4 One-dimensional Flow Analysis with Energy Losses 98 
3.5 Aerodynamic Phenomena and Design Parameters 104

3.6 Three-dimensional Flow Models 120

3.7 Compressor Characteristics and Flow Range 127

3.8 Impeller Stresses and Blade Vibrations 137

3.9 Design of a Single-stage Radial Flow Compressor 141

4. The Radial Flow Turbine 147

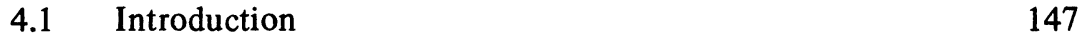

$\begin{array}{ll}4.2 & \text { Elementary Theory } \\ 4.3 & 147\end{array}$

4.3 One-dimensional Flow Analysis 154

$\begin{array}{lll}4.4 & 167\end{array}$

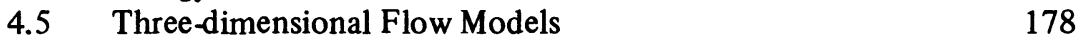

$\begin{array}{lll}4.6 & \text { Unsteady Flow } & 180\end{array}$

4.7 Turbine Characteristics and Flow Range 184

4.8 Turbine Rotor Stresses and Blade Vibrations 189

4.9 Design of the Single-stage Radial Flow Turbine 190

5. The Axial Flow Turbine 194

$\begin{array}{lll}5.1 & \text { Introduction } & 194\end{array}$

$\begin{array}{lll}5.2 & \text { Elementary Theory } & 194\end{array}$

5.3 Vortex Blading 203

5.4 Blade Profile, Spacing and Chord Length 209

5.5 Energy Losses and Blade Profiles 213

5.6 Three-dimensional Flow Models 225

$\begin{array}{lll}5.7 & \text { Inlet and Exhaust Casings } & 227\end{array}$

5.8 Partial Admission and Unsteady Flow 230

5.9 Turbine Characteristics and Flow Range 236

5.10 Blade Stress, Fixing and Vibration 239

5.11 Design of a Single-stage Axial Flow Turbine 242

6. Constant Pressure Turbocharging 246

$\begin{array}{lll}6.1 & \text { Introduction } & 246\end{array}$

6.2 The Energy Available in the Exhaust System 246

6.3 Constant Pressure Turbocharging 248

6.4 Four-stroke Engines with Constant Pressure Turbocharging 254

6.5 Two-stroke Engines with Constant Pressure Turbocharging 259

7. Pulse Turbocharging 264

$\begin{array}{lll}7.1 & \text { Introduction } & 264\end{array}$

7.2 The Pulse Turbocharging System 264

7.3 Four-stroke Engines with Pulse Turbocharging 278

7.4 Two-stroke Engines with Pulse Turbocharging 283

8. Pulse Converters and Summary of Turbocharging Systems 287

$\begin{array}{lll}8.1 & \text { Introduction } & 287\end{array}$

8.2 Simple Pulse Converters 290 
8.3 The Application of Pulse Converters to Two-stroke Engines 292

8.4 The Application of Pulse Converters to Four-stroke Engines 299

8.5 Engine Arrangements, Firing Order and Valve Timing 302

8.6 Multi-ntry Pulse Converters 304

8.7 Summary of Turbocharging Systems 312

9. Charge Cooling, the Inlet and Exhaust Systems 317

$\begin{array}{lll}9.1 & \text { Charge Cooling } & 317\end{array}$

9.2 The Design of Charge Coolers 322

9.3 Charge Air Cooling and Engine Performance 326

9.4 The Inlet System 330

9.5 The Exhaust System 336

10. Turbocharger Matching 340

$\begin{array}{lll}10.1 & \text { Introduction } & 340\end{array}$

10.2 Air Flow Characteristics of Engine and Turbocharger 343

10.3 Matching for Constant Speed Operation 349

10.4 Matching the Marine Engine 351

10.5 Matching for Diesel-Electric Traction 356

10.6 Matching for Other Industrial Duties 357

10.7 Matching the Four-stroke Automotive Engine 357

10.8 Matching the Two-stroke Automotive Engine 369

10.9 Changes in Ambient Conditions 371

11. High-output Turbocharging 378

$\begin{array}{lll}11.1 & \text { Introduction } & 378\end{array}$

$\begin{array}{ll}11.2 & \text { Engine Limitations } \\ 11.3 & 380\end{array}$

11.3 Single-stage Turbocharger Limitations 389

11.4 Single-stage Turbocharging of Marine and Industrial Engines 391

11.5 Two-stage Turbocharging of Marine and $\begin{array}{ll}\text { Industrial Engines } & 392\end{array}$

11.6 Two-stage Turbocharging of Vehicle-type Engines 397

11.7 Variable Geometry Turbocharging 401

11.8 'Hyperbar' Turbocharging 404

11.9 Compound Engines $\quad 409$

11.10 Insulated Engines $\quad 413$

12. Transient Response of Turbocharged Engines 418

$\begin{array}{lll}12.1 & \text { Introduction } & 418\end{array}$

12.2 The Importance of Rapid Response 421

12.3 Industrial Engines $\quad 423$

12.4 Vehicle Engines $\quad 430$

12.5 Energy Addition 435 
13. Turbocharging the Petrol Engine 441

13.1 Introduction 441

13.2 Petrol Engine Combustion and Knock 441

13.3 Compression Ratio and Boost Pressure 443

13.4 Ignition Timing and Knock 445

13.5 Charge Air Cooling 450

13.6 Carburation and Fuel Injection 450

13.7 Inlet and Exhaust Manifolds 456

13.8 Turbocharger Boost Pressure Control System 457

13.9 Valve Timing 464

13.10 Engine Performance 466

13.11 Exhaust Emissions $\quad 471$

13.12 Racing Engines $\quad 474$

13.13 Aircraft Engines 474

13.14 Stratified Charge Engines 476

13.15 Turbocharger Lag 477

14. Diesel Engine Exhaust Emissions and Noise 482

14.1 Introduction 482

14.2 Combustion 482

14.3 Formation of Pollutants 485

14.4 Emissions from Naturally Aspirated Engines 491

14.5 The Effect of Turbocharging 493

14.6 Charge Air Cooling 497

14.7 Turbocharging with Retarded Injection 499

14.8 Turbocharging with Exhaust Gas Recirculation 502

14.9 Turbocharging with High Injection Rates 504

14.10 Other Methods of Pollutant Reduction 504

14.11 Diesel Engine Noise $\quad 504$

14.12 Air Inlet Noise 506

14.13 Exhaust Noise 508

14.14 Combustion-generated Noise $\quad 509$

14.15 Mechanical Noise $\quad 514$

15. Modelling 517

15.1 Introduction 517

15.2 Simple Matching Calculation Techniques 517

15.3 Quasi-steady Methods $\quad 525$

15.4 The Energy Equation $\quad 528$

15.5 Gas Property Relationships $\quad 530$

15.6 Combustion 531

15.7 Heat Transfer 535

15.8 Flow through Valves and Ports $\quad 540$

15.9 The Scavenging Process 543

15.10 The Turbocharger 545 
15.11 Engine Friction

15.12 Solution of the Energy Equation - 'Filling and Emptying' Models

15.13 The Method of Characteristics

566

15.14 Transient Response Models

584

Index

595 


\section{Preface}

The turbocharger was invented a surprisingly long time ago but only relatively recently has it been an accepted component on all but very small diesel engines. After several false starts they are now also being used on petrol engines. Unlike most other components of an engine, the turbocharger can radically transform the performance of the engine and is therefore very much a critical component. As a result more engineers need to understand how and why it does what it does.

The characteristics of turbomachines are fundamentally different from those of reciprocating machines, hence the combination of turbocharger and engine has many complex characteristics. Yet engineers with diesel or petrol engine experience have little knowledge of turbomachines, and vice versa, and are therefore not well equipped to optimise the combination. This book is an attempt to help these engineers by explaining the principles of turbocharging, with special emphasis on the interactions between engine and turbocharger. Many examples of the current practice of turbocharging are also given to explain how the principles can be used to advantage. Although examples relating to large industrial and marine engines are not omitted, preference has deliberately been given to examples of practice on automotive (truck-type) diesel engines for several reasons. Firstly turbocharging is longer established on marine and industrial engines and hence the principles are better known in that industry. Secondly engine designers, development engineers and users who are new to turbocharging are mainly involved with truck and passenger car diesel engines.

The application of turbocharging to passenger car petrol engines has many unique features and therefore a special chapter has been devoted to this subject.

The authors, as academics, are firmly convinced that an understanding of the basic theory underlying a subject will lead the engineer to make wiser decisions. It is common practice to present this theory to students through mathematics, as the language of the engineer. This book is aimed at both the student and the practising engineer and the authors have recognised that the latter finds a mathematical approach tedious. As far as possible therefore explanations of principles have been presented in words and not through mathematics, so that the book is more readable than it would otherwise be. However, the techniques of analysis, mathematics and computer-aided design are now so useful to the 
engine designer that they should not be ignored. The mathematical representation of turbocharged engines has therefore been treated in a chapter of its own at the end of the book (chapter 15).

The organisation of the book is based on the premise that most readers will know more about engines than turbomachines. Following a brief over-all introduction to turbocharging, chapters 2 to 5 are devoted to the construction of turbochargers and the principles of radial compressors and radial and axial turbines, with reference to the turbocharger application (axial compressors are not used on turbochargers, being more suited for larger and more expensive gas turbines). Some readers may wish to omit the detailed description of flow processes in the turbomachines. Chapters 6 to 9 are concerned with turbocharging systems and the best methods of utilising exhaust gas energy via the turbocharger. Chapter 10 describes the critical task of matching the turbomachine to the engine to achieve optimum performance of the combination for all the common applications. Chapters $11,12,13$ and 14 are concerned with factors specific to or important in certain applications such as high-output turbocharging, transient performance, applications to petrol engines and the effect of turbocharging on exhaust emissions. The final chapter (15) has been mentioned above.

The authors are indebted to a large number of individuals, companies and organisations who have helped them in the preparation of this book. In particular, thanks are due to Professor F.J. Wallace, B.E. Walsham, I.W. Goodlet, E. Meier, Dr M. Marzouk, past and present students, Garrett-AiResearch, Holset Engineering Co. Ltd, Brown Boveri et Cie and Napier Turbochargers.

Mrs U. Harris, Mrs S. Boyle and Mrs M. Parsons have stoically retyped and redrawn as the authors have changed the manuscript.

Finally the authors are grateful to I.Mech.E., SAE, ASME, VDI, CIMAC, FISITA, MTZ, Butterworths, and Longman for permission to reproduce many of the illustrations used in the book.

N. WATSON

M. S. JANOTA

Marian Janota died shortly before the publication of this book. We had completed every stage in preparing the book but sadly he did not see the final bound volume. 


\section{Acknowledgements}

The authors wish to make acknowledgement to the following publishers for permission to reproduce figures from the texts indicated below

\section{Longman Group Ltd}

Gas Turbine Theory, by H. Cohen, G.F.C. Rogers and H.I.H. Saravanamuttoo.

Springer Verlag

Supercharging of Internal Combustion Engines by K. Zinner.

\section{G.T. Foulis}

Gas Flow in the Internal Combustion Engine by W.J.D Annand and G.E. Roe.

In addition a number of figures from papers by the authors and other authors have been reproduced by permission of ASME, Brown Boveri Review, CIMAC, Diesel \& Gas Turbine Progress, I.Mech.E., MTZ, SAE and VDI. 


\section{Nomenclature}

$\begin{array}{llc}a & \text { sonic velocity } & \mathrm{m} / \mathrm{s} \\ a^{\prime} & \text { non-dimensional sonic velocity, } a / a_{\mathrm{ref}} & - \\ A & \text { area } & \mathrm{m}^{2} \\ \mathrm{ABDC} & \text { above bottom dead centre } & - \\ A D R & \text { air delivery ratio } & - \\ A F R & \text { air/fuel ratio } & - \\ A R & \text { area ratio } & - \\ A S & \text { aspect ratio } & - \\ b & \text { width } & \mathrm{m} \\ B & \text { cylinder bore } & \mathrm{m} \\ \mathrm{BBDC} & \text { below bottom dead centre } & - \\ \mathrm{BDC} & \text { bottom dead centre } & - \\ \mathrm{BMEP} & \text { brake mean effective pressure } & \mathrm{bar} \\ \mathrm{BS} & \text { brake specific value } & - \\ \mathrm{BSAC} & \text { brake specific air consumption } & \mathrm{g} / \mathrm{kW} \mathrm{h} \\ \mathrm{BSFC} & \text { brake specific fuel consumption } & \mathrm{g} / \mathrm{kW} \mathrm{h} \\ c_{p} & \text { specific heat at constant pressure } & \mathrm{kJ} / \mathrm{kg} \mathrm{K} \\ c_{\nu} & \text { specific heat at constant volume } & \mathrm{kJ} / \mathrm{kg} \mathrm{K} \\ C & \text { velocity } & \mathrm{m} / \mathrm{s} \\ C & \text { non-dimensional velocity, } C / a_{\mathrm{ref}} & - \\ C d & \text { discharge coefficient } & - \\ C h & \text { enthalpy loss coefficient } & - \\ C_{\mathrm{LF}} & \text { lift coefficient, per unit length } & - \\ C P, C P R & \text { pressure recovery coefficient } & - \\ C P L & \text { pressure loss coefficient } & - \\ C R & \text { compression ratio } & - \\ C T Q & \text { torque coefficient } & - \\ D & \text { diameter } & \mathrm{m} \\ D f & \text { diffusion factor } & - \\ D I & \text { direct injection diesel engine } & - \\ D S & \text { specific diameter } & - \\ E & \text { energy } & \mathrm{kJ} \\ \mathrm{EC} & \text { exhaust port or valve closes } & \circ \\ \mathrm{EO} & \text { exhaust port or valve opens } & \end{array}$




\begin{tabular}{|c|c|c|}
\hline ER & expansion ratio & - \\
\hline EVC & exhaust valve closes & $\circ$ \\
\hline EVO & exhaust valve opens & $\circ$ \\
\hline$f$ & $\begin{array}{l}\text { frequency; friction factor; function; burnt fuel/ } \\
\text { air ratio }\end{array}$ & $\mathrm{Hz} ;-$ \\
\hline$F$ & equivalence ratio; force & $-; \mathrm{kN}$ \\
\hline$F B$ & fuel burnt & - \\
\hline$F B R$ & fuel burning rate & - \\
\hline$F L$ & frictional loss as torque & $\mathrm{N}$ m \\
\hline FMEP & frictional loss as loss of mean effective pressure & bar \\
\hline$F P$ & fuel prepared & kg \\
\hline$F R$ & fuel reacted & $\mathrm{kg}$ \\
\hline$h$ & height; specific enthalpy & $\mathrm{m} ; \mathrm{kJ} / \mathrm{kg}$ \\
\hline$H D$ & pressure head & $\mathrm{m}^{2} / \mathrm{s}^{2}$ \\
\hline hf & humidity factor & - \\
\hline HSU & Hartridge smoke units & - \\
\hline HP & high pressure & - \\
\hline$h t$ & heat transfer coefficient & $\mathrm{kW} / \mathrm{m}^{2} \mathrm{~K}$ \\
\hline$i$ & incidence angle; control volume number & ${ }^{\circ} ;-$ \\
\hline$I$ & section modulus (inertia) & $\mathrm{kg} \mathrm{m}^{2}$ \\
\hline IC & inlet port or valve closes & $\circ$ \\
\hline$I D$ & ignition delay & $\circ$ \\
\hline IDI & indirect injection diesel engine & - \\
\hline IMEP & indicated mean effective pressure & bar \\
\hline IO & inlet port or valve opens & $\circ$ \\
\hline IVC & inlet valve closure & - \\
\hline$k$ & conductivity; constant & $\mathrm{kW} / \mathrm{m} \mathrm{K} ;-$ \\
\hline$K$ & general constant & - \\
\hline KE & kinetic energy & $\mathbf{J}$ \\
\hline$l$ & length, chord & $\mathrm{m}$ \\
\hline$L$ & losses & - \\
\hline$L F$ & lift force & $\mathbf{k N}$ \\
\hline LP & low pressure & - \\
\hline$L T$ & load torque & $\mathrm{N}$ m \\
\hline$m$ & mass & kg \\
\hline$\dot{m}$ & mass flow rate & $\mathrm{kg} / \mathrm{s}$ \\
\hline$M$ & Mach number & \\
\hline MBT & maximum brake torque & - \\
\hline$M R$ & Mach number ratio & - \\
\hline$n$ & number & - \\
\hline$N$ & rotational speed & $\mathrm{rev} / \mathrm{min}$ \\
\hline NA & naturally aspirated & - \\
\hline$N D$ & specific diameter & - \\
\hline$N S$ & specific speed & - \\
\hline$N u$ & Nusselt number & - \\
\hline$P$ & pressure & bar \\
\hline PE & potential energy & $\mathbf{J}$ \\
\hline$P P$ & partial pressure & bar \\
\hline
\end{tabular}




\begin{tabular}{|c|c|c|}
\hline ppm & parts per million (concentration) & - \\
\hline $\operatorname{Pr}$ & Prandtl number & - \\
\hline$P R$ & pressure ratio & - \\
\hline$Q$ & heat transfer & $\mathrm{kJ}$ \\
\hline $\bar{Q}$ & heat transfer rate & $\mathrm{kW}$ \\
\hline$r$ & radius & $\mathrm{m}$ \\
\hline$R$ & gas constant & $\mathrm{kJ} / \mathrm{kg} \mathrm{K}$ \\
\hline $\operatorname{Re}$ & Reynolds number & - \\
\hline$R N$ & degree of reaction & - \\
\hline RPM & revolutions per minute & $\min ^{-1}$ \\
\hline$s$ & specific entropy & $\mathrm{kJ} / \mathrm{kg} \mathrm{K}$ \\
\hline$s p$ & circumferential spacing (pitch) & $\mathrm{m}$ \\
\hline$t$ & time & s \\
\hline$t^{\prime}$ & non-dimensional time, $t a_{\text {ref }} / l_{\text {ref }}$ & - \\
\hline$T$ & temperature & $\mathrm{K}$ \\
\hline $\mathrm{TC}$ & turbocharged & - \\
\hline TDC & top dead centre & - \\
\hline th & thickness & $\mathrm{m}$ \\
\hline$T Q$ & torque & $\mathrm{N} \mathrm{m}$ \\
\hline$u$ & specific internal energy & $\mathrm{kJ} / \mathrm{kg}$ \\
\hline$U$ & rotor tip speed & $\mathrm{m} / \mathrm{s}$ \\
\hline $\boldsymbol{v}$ & specific volume & $\mathrm{m}^{3} / \mathrm{kg}$ \\
\hline $\boldsymbol{V}$ & volume & $\mathrm{m}^{3}$ \\
\hline V & volumetric flow rate & $\mathrm{m}^{3} / \mathrm{s}$ \\
\hline vo & valve opening period & \\
\hline$w$ & work done; velocity relative to blade & $\mathrm{kJ} ; \mathrm{m} / \mathrm{s}$ \\
\hline$\dot{W}$ & power & $\mathrm{kW}$ \\
\hline$x$ & distance; relative change in rack movement & $\mathrm{m}$ \\
\hline$x^{\prime}$ & non-dimensional distance, $x / l_{\text {ref }}$ & - \\
\hline$y$ & relative change in speed & $\mathrm{m} / \mathrm{s}$ \\
\hline$z$ & number of nozzles or vanes & - \\
\hline$Z$ & number of blades & - \\
\hline$\alpha$ & angle & $\circ$ \\
\hline$\beta$ & $\begin{array}{l}\text { backsweep angle; phase proportionality factor; } \\
\text { Riemann parameter }\end{array}$ & ${ }^{\circ} ;-$ \\
\hline $\begin{array}{l}\gamma \\
\Delta\end{array}$ & $c_{p} / c_{v}$ & - \\
\hline$\epsilon$ & $\begin{array}{l}\text { effective impeller exit area ratio; arc of admission; } \\
\text { effectiveness; emissivity }\end{array}$ & $-;^{\circ} ;-;-$ \\
\hline$\eta$ & efficiency & - \\
\hline$\theta$ & angle & $\circ$ \\
\hline$\lambda$ & Riemann parameter & - \\
\hline$\Lambda$ & $r_{\text {hub }} / r_{\text {tip }}$ & - \\
\hline$\mu$ & dynamic viscosity; energy transfer coefficient & $\mathrm{kg} / \mathrm{m} \mathrm{s} ; \mathrm{kg} \mathrm{m} / \mathrm{s}$ \\
\hline$\nu$ & Poisson's ratio; kinematic viscocity & $-; \mathrm{m}^{2} / \mathrm{s}^{2}$ \\
\hline$\rho$ & density & $\mathrm{kg} / \mathrm{m}^{3}$ \\
\hline$\sigma$ & $\begin{array}{l}\text { compressor slip factor; Stephan-Boltzmann } \\
\text { constant; stress }\end{array}$ & $\underset{\mathrm{kN} / \mathrm{m}^{2}}{-; \mathrm{kW} / \mathrm{m}^{2} \mathrm{~K}^{4}}$ \\
\hline
\end{tabular}




\section{Subscripts}

$\begin{array}{llll}\text { a } & \text { axial; air; ambient } & \text { n } & \text { nozzle } \\ \text { alt } & \text { altitude } & \text { NOM } & \text { nominal } \\ \text { an } & \text { anemometer } & \text { p } & \text { exhaust pipe; polytropic } \\ \text { APP } & \text { apparent } & p & \text { pressure } \\ \text { b } & \text { blade; backsweep } & \text { P } & \text { profile } \\ \text { bu } & \text { bursting } & \text { pis } & \text { piston } \\ \text { c } & \text { compressor; centrifugal } & \text { q } & \text { casing (exit) } \\ \text { carb } & \text { carburettor } & \text { r } & \text { radial; root } \\ \text { cl, C } & \text { clearance } & \text { R } & \text { rotor } \\ \text { com } & \text { combustion } & \text { ref } & \text { reference } \\ \text { cool } & \text { coolant } & \text { rel } & \text { relative } \\ \text { cyl } & \text { cylinder } & \text { s } & \text { isentropic } \\ \text { dif } & \text { diffuser } & \text { S } & \text { secondary } \\ \text { e } & \text { engine; trailing edge } & \text { ss } & \text { isentropic throughout } \\ \text { es } & \text { end of sector } & \text { sf } & \text { surface } \\ \text { ex } & \text { exhaust } & \text { sh } & \text { shroud } \\ \text { f } & \text { fuel } & \text { st } & \text { stalled } \\ \text { fb } & \text { fuel burnt } & \text { sto } & \text { stoichiometric } \\ \text { for } & \text { formation } & \text { svp } & \text { saturated vapour pressure } \\ \text { fr } & \text { friction } & \text { sw } & \text { swept } \\ \text { g } & \text { gas } & \text { t } & \text { turbine; tip } \\ \text { gb } & \text { gas bending } & \text { tc } & \text { turbocharger } \\ \text { ge } & \text { gas exchange } & \text { th } & \text { throat } \\ \text { h } & \text { hoop; hub } & \text { tot } & \text { total } \\ \text { ht } & \text { heat transfer } & \text { TS } & \text { total to static } \\ \text { i } & \text { instantaneous } & \text { TT } & \text { total to total } \\ \text { ic } & \text { inlet casing } & \text { u } & \text { unburnt fuel } \\ \text { imp } & \text { impeller } & \text { ult } & \text { ultimate } \\ \text { ind } & \text { indicated } & v & \text { volume } \\ \text { j } & \text { control volume port } & \text { vol } & \text { volumetric } \\ \text { k } & \text { casing (inlet) } & \text { w } & \text { water, windage } \\ \text { l } & \text { load } & \text { z } & \text { start of compression } \\ \text { m } & \text { manifold; mean } & * & \text { naturally aspirated } \\ \text { max } & \text { maximum } & 0 & \text { stagnation } \\ \text { min } & \text { minimum } & \theta & \text { tangential } \\ \text { mot } & \text { motored } & \omega & \text { whirl } \\ & & & \end{array}$

